\title{
Impacts of Using Mineral Fertilization Combined with Sewage Sludge in the Amendment of Luvisol on Oat Crop I. Influence on Yield and Mineral Nutrition
}

\author{
LEONARD ILIE ${ }^{1}$, MIRCEA MIHALACHE ${ }^{1}$, ROXANA MARIA MADJAR ${ }^{1}$, \\ CATALINA CALIN ${ }^{2}$, GINA VASILE SCAETEANU ${ }^{*}$ \\ ${ }^{1}$ University of Agronomic Sciences and Veterinary Medicine of Bucharest, 59 Marasesti Blvd., 011464, Bucharest, \\ Romania \\ ${ }^{2}$ Petroleum-Gas University of Ploiesti, 39 Bucharest Av., 100680, Ploiesti, Romania
}

\begin{abstract}
The present paper illustrates the results obtained on oat (Avena sativa L.), Someșan variety, concerning growth, grains and straw yields and also of macroelements accumulation $(N, P, K, C a$, $\mathrm{Mg}$ ) when various doses of sewage sludge were applied associated or not with mineral fertilization. Sewage sludge application produced significant increase of plant height starting with equivalent dose of $100 \mathrm{~kg} \mathrm{N/ha,} \mathrm{meanwhile} \mathrm{the} \mathrm{highest} \mathrm{height} \mathrm{was} \mathrm{observed} \mathrm{in} \mathrm{the} \mathrm{case} \mathrm{of} \mathrm{plants} \mathrm{fertilized} \mathrm{with} \mathrm{doses}$ equivalent with 300 and $400 \mathrm{~kg} N / \mathrm{ha}$. With the increase of sewage sludge dose it has been observed the straw yield increase, this being statistically assured starting with sewage sludge equivalent dose of $100 \mathrm{~kg} \mathrm{N/ha}$. Sewage sludge fertilization, accompanied or not by mineral fertilizers, evidenced that nitrogen contents in oat grains increases with applied sewage dose, being significant from an equivalent dose of $200 \mathrm{~kg} \mathrm{N/ha}$. Low sewage doses equivalent with 200-300 $\mathrm{kg} \mathrm{K} / \mathrm{ha}$ evidenced for potassium concentration in oat grains a significant decrease in comparison with untreated variant, meanwhile mineral fertilization generated a significant increase of potassium levels in oat grains. Calcium contents in oat grains present a significant increase after sewage sludge fertilization and at a dose equivalent with $600 \mathrm{~kg} \mathrm{~N} / \mathrm{ha}$, the calcium levels (0.24\%) increased 3 times in comparison with untreated variant (0.08\%). Sewage sludge fertilization, associated or not with mineral fertilizers, did not produced significant changes of magnesium levels in oat grains, found concentrations being considered as normal values.
\end{abstract}

Keywords: grains, mineral fertilization, oat, sewage sludge, yield.

\section{Introduction}

Resulted from municipal wastewater treatment plants, sewage sludge is a nutrient rich organic material, used as fertilizer and soil conditioner. Considerable number of research papers has been accomplished worldwide on the effects of sewage sludge on soil and various crops. Hence, some studies indicated that successive application during seven years of $100 \mathrm{t} / \mathrm{ha}$ municipal sewage sludge for wheat and maize crops produced an increase with a percent of organic carbon from soil [1,2]. Other researches evidenced that sewage sludge application presented a positive influence on the content of total organic carbon and humus fractions [3]. Organic fertilization with compost obtained from municipal sludge with a dose of compost equivalent to $400 \mathrm{~kg} \mathrm{~N} / \mathrm{ha}$ led to significant increases of mobile phosphorus levels in soil [4].

Mihalache et al [5] reported that sewage sludge application generate significant increase of soil organic carbon, total nitrogen, mobile forms of phosphorus and potassium, the highest effects being encountered for $240 \mathrm{t} / \mathrm{ha}$ sewage sludge dose.

There are many scientific reports that highlight the enhancement of crop productivity and crop quality parameters after sewage sludge application. Accordingly, application of $0,40,80,120,240 \mathrm{t} / \mathrm{ha}$ sewage sludge at rice crop evidenced that rate of $240 \mathrm{t} / \mathrm{ha}$ produced highest number of filled grains per panicle, dry weight of grains and weight of 1000 grains [6]. The efficiency of sewage sludge

\footnotetext{
*email: ginavasile2000@yahoo.com
} 
application on maize [7,8], sunflower [9,10], wheat [11], growth, yield, macroelements and metals accumulation was evidenced and reported. Also, positive effects on yield of dwarf bean [12] and growth of flax [13] have been reported at application of different doses of sewage sludge.

Fertilization with compost from municipal sludge associated with mineral fertilization led to better yields for various crops (oat, maize, soybean) in comparison with one type of fertilization [4]. Better crop parameters could be also achieved by using some promising materials, such as essential oils microcapsules [14].

Because of the presence of toxic heavy metals [15], organic pollutants [16-18] and pathogenic organisms [18,19], sewage sludge may present environmental risk. To eliminate the presence of pathogens in sewage sludge it is recommended to adopt some techniques as digestion and/or radiation [20]. A positive effect of sewage sludge (irradiated or not) was reported regarding dry matter yield and nitrogen uptake for wheat crop [20].

Having in view the acknowledged beneficial influence of sewage sludge application to different crops, the purpose of the present research was to investigate the sewage sludge effects on growth, yield responses and macronutrients $(\mathrm{N}, \mathrm{P}, \mathrm{K}, \mathrm{Ca}, \mathrm{Mg}$ ) accumulation for oat (Avena sativa $\mathrm{L}$.).

The developed experimental model was a bifactorial one $(7 \times 2)$ and the studied factors were: A factor - sewage sludge fertilization with 7 degrees representing equivalent doses varying between 0 $600 \mathrm{~kg} / \mathrm{ha}$ and $\mathbf{B}$ factor - mineral fertilization (NPK) with 2 degrees: $\mathrm{b}_{1}-\mathrm{N}_{0} \mathrm{P}_{0} \mathrm{~K}_{0}$ and $\mathrm{b}_{2}-$ $\mathrm{N}_{100} \mathrm{P}_{100} \mathrm{~K}_{100}$.

\section{Materials and methods}

\subsection{Experimental design}

In order to study the influence of sewage sludge application on yield and mineral nutrition, was used oat (Avena sativa L.), Someșan variety, as test plant cultivated in experimental pots. For experimental model which is a bifactorial one (7x2) (table 1), it were used 56 vegetation pots $(20 \mathrm{~L}$ capacity), each treatment (totalizing 14) in four repetitions. For experiments was used soil collected from $A_{0}$ horizon of luvisol meanwhile sewage sludge that was used in experiment was collected from the Wastewater Treatment Plant (WWTP) from Piteşti.

Table 1. Description of bifactorial experimental model

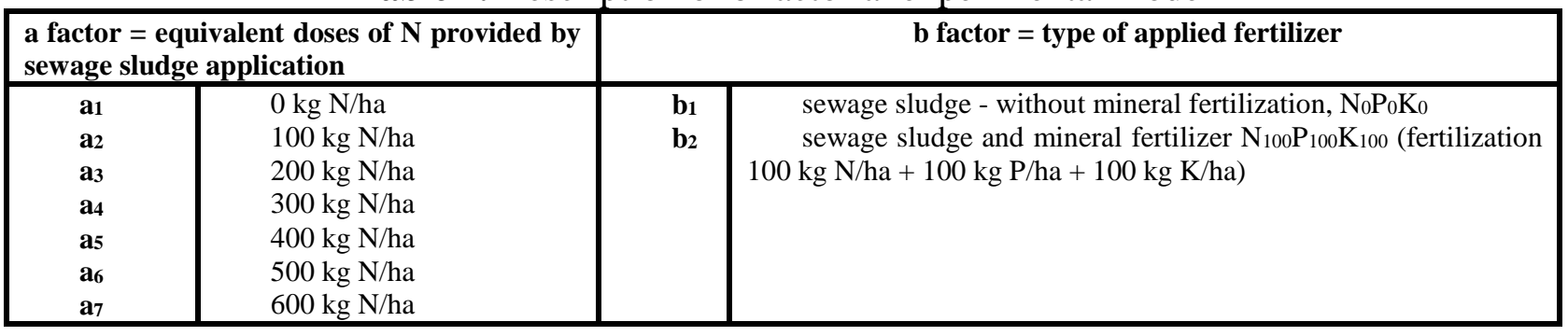

\subsection{Chemical characterization of soil and sewage sludge}

Soil and sewage sludge were fully characterized and the performed analyses are presented in Table 2.

Table 2. Chemical analyses performed on soil and sewage sludge

\begin{tabular}{|c|c|c|c|}
\hline Parameter & Soil & $\begin{array}{c}\text { Sewage } \\
\text { sludge }\end{array}$ & Method and apparatus \\
\hline $\mathrm{pH}$ & $\checkmark$ & $\checkmark$ & potentiometric method (aqueous suspension, 1:2.5, w/v); pH-meter \\
Hanna intruments.
\end{tabular}




\begin{tabular}{|c|c|c|c|}
\hline Mobile potassium $\left(\mathrm{K}_{\mathrm{AL}}\right)$ & $\checkmark$ & - & $\begin{array}{c}\text { Egner-Riehm-Domingo method; atomic emission spectrometry } \\
\text { (AES); Sherwood Scientific 420 flame photometer. }\end{array}$ \\
\hline Total nitrogen $\left(\mathrm{N}_{\mathrm{total}}\right)$ & $\checkmark$ & $\checkmark$ & Kjeldahl method; Gerhardt Vapodest automatic analyzer. \\
\hline Total phosphorus $\left(\mathrm{P}_{\mathrm{total}}\right)$ & - & $\checkmark$ & $\begin{array}{c}\text { spectrophotometrically, as molybdenum blue; Cecil 2041 UV/VIS } \\
\text { spectrophotometer. }\end{array}$ \\
\hline Total potassium (Ktotal) & - & $\checkmark$ & $\begin{array}{c}\text { atomic emission spectrometry (AES); Sherwood Scientific 420 } \\
\text { flame photometer. }\end{array}$ \\
\hline Metals total forms & $\checkmark$ & $\checkmark$ & $\begin{array}{c}\text { atomic absorption spectrometry (AAS), after aqua regia digestion } \\
\text { [21,22]; Thermo Scientific AA Spectrometer. }\end{array}$ \\
\hline
\end{tabular}

\subsection{Plant sampling and chemical analysis}

Plant samples were processed and then analyzed according to methodology described in a previous paper [7], based on Singh and Agrawal researches [23]. Total nitrogen content was evaluated using Kjeldahl method (Gerhardt Vapodest automatic analyzer), meanwhile total phosphorus was assessed spectrophotometrically as molybdenum blue (Cecil 2041 UV/VIS spectrophotometer) and potassium using AES technique (Sherwood Scientific 420 flame photometer). Contents of calcium and magnesium were determined after filtering the digested samples through AAS technique (Thermo Scientific AA Spectrometer).

\section{Results and discussions}

\subsection{Soil and sewage sludge chemical characterization}

The soil used in this experiment was taken from Ao horizon of Luvisol [24]. It had a loam texture, presented moderately acidic reaction ( $\mathrm{pH} 5.20)$, low carbon organic content (1.19\%) and low levels of macronutrients: $\mathrm{N}_{\text {total }}-0.140 \%, \mathrm{P}_{\mathrm{AL}}-19 \mathrm{mg} / \mathrm{kg}$ and $\mathrm{K}_{\mathrm{AL}}-40 \mathrm{mg} / \mathrm{kg}$. The concentrations for metals (total forms) are: $\mathrm{Cd}-0.11 \mathrm{mg} / \mathrm{kg}, \mathrm{Co}-6.60 \mathrm{mg} / \mathrm{kg}, \mathrm{Cr}-19 \mathrm{mg} / \mathrm{kg}, \mathrm{Cu}-12 \mathrm{mg} / \mathrm{kg}, \mathrm{Mn}-500 \mathrm{mg} / \mathrm{kg}$, $\mathrm{Ni}-15 \mathrm{mg} / \mathrm{kg}, \mathrm{Pb}-13 \mathrm{mg} / \mathrm{kg}$ and $\mathrm{Zn}-48 \mathrm{mg} / \mathrm{kg}$.

Sewage sludge chemical characteristics are depicted in table 3. It was analyzed 9 samples and according to the results, investigated sewage sludge contains high levels of organic matter (48.3\%, as average) and presents a balanced macronutrient composition which recommends it as fertilizer.

Concerning metal composition of sewage sludge, it must be respected European Directive 86/278/CEE [25] and Order of the Minister of Agriculture, Forests, Waters and Environment no.344/2004 [26], metal content being a restrictive factor for sewage sludge application.

Excepting cadmium concentration which is 7.2 times higher than limit imposed by Order of the Minister of Agriculture, Forests, Waters and Environment no.344/2004 [26], found metal contents (as total form) in analyzed sewage sludge indicate that there are no restrictions concerning application it on agricultural soils and meet the requirements imposed by legislation [25,26].

Table 3. Sewage sludge chemical characterization

\begin{tabular}{|c|c|c|c|c|c|}
\hline \multirow[t]{2}{*}{ Sewage parameters } & \multirow{2}{*}{$\begin{array}{l}\text { Determined } \\
\text { values } \\
\text { (min-max) }\end{array}$} & \multirow{2}{*}{$\begin{array}{l}\text { Average value } \pm \\
\text { standard deviation }\end{array}$} & \multirow{2}{*}{$\begin{array}{c}\text { Coefficient of } \\
\text { variation, \% }\end{array}$} & \multicolumn{2}{|c|}{ Restricted value } \\
\hline & & & & $\begin{array}{c}\text { Order } 344 / 2004 \\
\text { Romania [26] }\end{array}$ & $\begin{array}{c}\text { Directive } \\
\text { 86/278/EEC } \\
{[25]}\end{array}$ \\
\hline Water content, $\%$ & $74.2-84.6$ & $\mathbf{7 7 . 8} \pm 3.3$ & 4.2 & - & - \\
\hline $\mathrm{pH}$ & $6.83-6.90$ & $6.87 \pm 0.02$ & 0.3 & - & - \\
\hline Organic matter, \% & $47.2-50.0$ & $\mathbf{4 8 . 3} \pm 0.9$ & 1.9 & - & - \\
\hline $\mathrm{N}_{\text {total }}, \%$ & $1.82-2.53$ & $\mathbf{2 . 1 1} \pm 0.22$ & 10.4 & - & - \\
\hline $\mathrm{P}_{\text {total, }} \%$ & $0.66-0.79$ & $\mathbf{0 . 7 2} \pm 0.05$ & 6.9 & - & - \\
\hline $\mathrm{K}_{\text {total, }} \%$ & $0.33-0.48$ & $\mathbf{0 . 4 0} \pm 0.05$ & 12.5 & - & - \\
\hline $\mathrm{Cd}, \mathrm{mg} / \mathrm{kg}$ & $54-84$ & $\mathbf{7 2} \pm 9$ & 12.5 & 10 & $20-40$ \\
\hline $\mathrm{Co}, \mathrm{mg} / \mathrm{kg}$ & $5.5-8.2$ & $\mathbf{6 . 6} \pm 0.8$ & 12.1 & 50 & - \\
\hline $\mathrm{Cr}, \mathrm{mg} / \mathrm{kg}$ & $122-145$ & $\mathbf{1 3 5} \pm 8$ & 5.9 & 500 & - \\
\hline $\mathrm{Cu}, \mathrm{mg} / \mathrm{kg}$ & $137-166$ & $154 \pm 11$ & 7.1 & 500 & $1000-1750$ \\
\hline $\mathrm{Mn}, \mathrm{mg} / \mathrm{kg}$ & $373-436$ & $400 \pm 19$ & 4.8 & - & - \\
\hline $\mathrm{Ni}, \mathrm{mg} / \mathrm{kg}$ & $37-42$ & $\mathbf{4 0} \pm 2$ & 5.0 & 100 & $300-400$ \\
\hline
\end{tabular}




\begin{tabular}{|c|c|c|c|c|c|}
\hline $\mathrm{Pb}, \mathrm{mg} / \mathrm{kg}$ & $88-135$ & $\mathbf{1 0 6} \pm 15$ & 14.2 & $\mathbf{3 0 0}$ & $\mathbf{7 5 0 - 1 2 0 0}$ \\
\hline $\mathrm{Zn}, \mathrm{mg} / \mathrm{kg}$ & $1290-1932$ & $\mathbf{1 4 9 2} \pm 184$ & 12.3 & $\mathbf{2 0 0 0}$ & $\mathbf{2 5 0 0 - 4 0 0 0}$ \\
\hline
\end{tabular}

\subsection{Influence of sewage sludge application on height, grains yield and straw yield}

The data regarding the influence of sewage sludge application associated or not with mineral fertilizers on height of oat plants Someșan variety, evidenced that sewage sludge application produce significant increase of plant height starting with equivalent dose of $100 \mathrm{~kg} \mathrm{~N} / \mathrm{ha}$ (Table 4). The highest height was observed in the case of plants fertilized with doses equivalent with 300 and $400 \mathrm{~kg} \mathrm{~N} / \mathrm{ha}$.

The mixed application of sewage sludge and mineral fertilizers resulted in no statistically assured increases of oat plant height, these being similar with those obtained after sewage sludge fertilization solely.

With respect to grains yield, the application of sewage sludge produced very significant increase of grains yield; the lowest value, as average (30g/pot) was encountered for sewage sludge without mineral fertilization variants, meanwhile the highest one, as average $(95 \mathrm{~g} / \mathrm{pot})$ was obtained for sewage dose equivalent with $500 \mathrm{~kg} \mathrm{~N} / \mathrm{ha}$ and $600 \mathrm{~kg} \mathrm{~N} / \mathrm{ha}$ (Table 4). Mineral fertilization led to significant oat grains yield in comparison with unfertilized variant.

With the increase of sewage sludge dose it has been observed the straw yield increase, the increase being statistically assured starting with sewage sludge equivalent dose of $100 \mathrm{~kg} \mathrm{~N} / \mathrm{ha}$. The lowest straw yield, as average (25g/pot) was obtained for sewage sludge unfertilized variants and the highest, as average $(100 \mathrm{~g} / \mathrm{pot})$ was obtained after application of sewage sludge dose equivalent with $600 \mathrm{~kg}$ N/ha (Table 4). Mineral fertilization increased significantly the straw yield.

Sewage sludge application associated with mineral fertilizers does not provide significant statistical increases of grains yield and straw yield but these parameters are slightly higher in comparison with the variants fertilized organic only.

Some researchers [27] evidenced that the highest oat yields were obtained when was applied a dose of sewage sludge equivalent with $400 \mathrm{~kg} \mathrm{~N} / \mathrm{ha}$. Also, sewage sludge treatments at oat crop at doses equivalent with $200 \mathrm{~kg} \mathrm{~N} / \mathrm{ha}$ led to the same yields as those obtained after application of $100 \mathrm{~kg} \mathrm{~N} / \mathrm{ha}$ as ammonium sulphate [27].

Mihalache et al. [5] evidenced that fertilization with sewage sludge favored yield increase, but the production decreased with the increasing the application rate of sewage sludge (at $120 \mathrm{t} / \mathrm{ha}$ for oat and $90 \mathrm{t} / \mathrm{ha}$ for sugar beet).

Table 4. Influence of sewage sludge application (without/with mineral fertilization) on height, grain yield and straw yield

\begin{tabular}{|c|c|c|c|c|c|c|c|c|c|c|}
\hline \multicolumn{2}{|c|}{ Sewage sludge } & \multicolumn{3}{|c|}{ Height, $\mathrm{cm}$} & \multicolumn{3}{|c|}{ Grains Yield, g } & \multicolumn{3}{|c|}{ Straw Yield, g } \\
\hline & & $\mathrm{b}_{1}$ & $\mathrm{~b}_{2}$ & Av. (b) & $\mathrm{b}_{1}$ & $\mathrm{~b}_{2}$ & Av. (b) & $\mathrm{b}_{1}$ & $\mathrm{~b}_{2}$ & Av. (b) \\
\hline $\mathrm{a}_{1}$ & $0 \mathrm{~kg} \mathrm{~N} / \mathrm{ha}$ & 59 & 86 & $73 a^{*}$ & 13 & 47 & $30 a^{*}$ & 13 & 36 & $25 a^{*}$ \\
\hline $\mathrm{a}_{2}$ & $100 \mathrm{~kg} \mathrm{~N} / \mathrm{ha}$ & 83 & 90 & $87 b$ & 55 & 74 & $65 b$ & 40 & 59 & $50 \mathrm{~b}$ \\
\hline $\mathrm{a}_{3}$ & $200 \mathrm{~kg} \mathrm{~N} / \mathrm{ha}$ & 87 & 94 & $91 \mathrm{c}$ & 73 & 90 & $82 \mathrm{c}$ & 55 & 74 & $65 c$ \\
\hline $\mathrm{a}_{4}$ & $300 \mathrm{~kg} \mathrm{~N} / \mathrm{ha}$ & 93 & 94 & $94 \mathrm{c}$ & 84 & 93 & $89 \mathrm{~d}$ & 65 & 86 & $76 \mathrm{~d}$ \\
\hline a5 & $400 \mathrm{~kg} \mathrm{~N} / \mathrm{ha}$ & 93 & 94 & $94 \mathrm{c}$ & 89 & 99 & $94 d$ & 75 & 100 & $88 \mathrm{e}$ \\
\hline a6 & $500 \mathrm{~kg} \mathrm{~N} / \mathrm{ha}$ & 91 & 91 & $91 \mathrm{c}$ & 89 & 100 & $95 \mathrm{~d}$ & 76 & 99 & $88 \mathrm{e}$ \\
\hline a7 & $600 \mathrm{~kg} \mathrm{~N} / \mathrm{ha}$ & 92 & 89 & $91 \mathrm{c}$ & 90 & 99 & $95 \mathrm{~d}$ & 90 & 109 & $100 \mathrm{f}$ \\
\hline & Av. (a) & $85 a^{*}$ & $91 \mathrm{~b}$ & - & $70 a^{*}$ & $86 b$ & - & $59 a^{*}$ & $80 \mathrm{~b}$ & - \\
\hline
\end{tabular}

$b_{1}$ - corresponds to $\mathrm{N}_{0} \mathrm{P}_{0} \mathrm{~K}_{0}$ (without mineral fertilization), $\mathrm{b}_{2}$ - corresponds to $\mathrm{N}_{100} \mathrm{P}_{100} \mathrm{~K}_{100}$ (mineral fertilization) Av. - average

*Mean values accompanied by same letter ( $\mathrm{a}$ or $\mathrm{b}$ ) does not present significant differences (Tukey multiple comparison test - significance level 0.05)

\subsection{Influence of sewage sludge application on $\mathrm{N}, \mathrm{P}, \mathrm{K}$ contents in grains}

Sewage sludge fertilization, accompanied or not by mineral fertilizers, evidenced that nitrogen contents in oat grains increases with applied sewage dose, being significant from an equivalent dose of $200 \mathrm{~kg} \mathrm{~N} / \mathrm{ha}$ (table 5). Mineral fertilization led to statistic significant increases of nitrogen level in oat grains. Association of sewage sludge with mineral fertilizers did not led to statistic significant changes 
of nitrogen content, the nitrogen levels being slightly higher than those obtained after sewage sludge application only.

The obtained data, regarding sewage sludge fertilization, associated or not with mineral fertilizers, evidenced that no significant changes were recorded for phosphorus levels in oat grains (Table 5).

Concerning potassium content in oat grains after sewage sludge application, associated or not with mineral fertilizers, it was observed that at low doses equivalent with $200-300 \mathrm{~kg} \mathrm{~N} / \mathrm{ha}$, potassium concentration in oat grains present a significant decrease in comparison with untreated variant (table 5). Mineral fertilization generated a significant increase of potassium levels in oat grains.

Association and application of organic and mineral fertilizers did not produce significant potassium concentration, the obtained concentrations being similar with those obtained after sewage sludge application only.

Average concentrations for phosphorus and potassium in oat grains are in agreement with values reported for oat grains [28] and cereal grains [29,30].

Table 5. Influence of sewage sludge application (without/with mineral fertilization) on

$\mathrm{N}, \mathrm{P}$ and $\mathrm{K}$ contents in grains

\begin{tabular}{|c|c|c|c|c|c|c|c|c|c|c|}
\hline \multicolumn{2}{|c|}{ Sewage sludge } & \multicolumn{3}{c|}{$\mathbf{N}, \%$} & \multicolumn{3}{c|}{ P, \% } & \multicolumn{3}{c|}{ K, \% } \\
\cline { 3 - 12 } & & $\mathrm{b}_{1}$ & $\mathrm{~b}_{2}$ & Av. (b) & $\mathrm{b}_{1}$ & $\mathrm{~b}_{2}$ & Av. (b) & $\mathrm{b}_{1}$ & $\mathrm{~b}_{2}$ & Av. (b) \\
\hline $\mathrm{a}_{1}$ & $0 \mathrm{~kg} \mathrm{~N} / \mathrm{ha}$ & 1.35 & 1.46 & $1.41 \mathrm{a}^{*}$ & 0.28 & 0.28 & $0.28 \mathrm{a}^{*}$ & 0.83 & 0.85 & $0.84 \mathrm{a}^{*}$ \\
\hline $\mathrm{a}_{2}$ & $100 \mathrm{~kg} \mathrm{~N} / \mathrm{ha}$ & 1.52 & 1.65 & $1.59 \mathrm{ab}$ & 0.28 & 0.29 & $0.29 \mathrm{a}$ & 0.76 & 0.77 & $0.77 \mathrm{ab}$ \\
\hline $\mathrm{a}_{3}$ & $200 \mathrm{~kg} \mathrm{~N} / \mathrm{ha}$ & 1.73 & 1.82 & $1.78 \mathrm{~b}$ & 0.29 & 0.29 & $0.29 \mathrm{a}$ & 0.67 & 0.70 & $0.69 \mathrm{~b}$ \\
\hline $\mathrm{a}_{4}$ & $300 \mathrm{~kg} \mathrm{~N} / \mathrm{ha}$ & 1.84 & 1.94 & $1.89 \mathrm{bc}$ & 0.32 & 0.32 & $0.32 \mathrm{a}$ & 0.67 & 0.76 & $0.72 \mathrm{~b}$ \\
\hline $\mathrm{a}_{5}$ & $400 \mathrm{~kg} \mathrm{~N} / \mathrm{ha}$ & 2.02 & 2.27 & $2.15 \mathrm{~cd}$ & 0.31 & 0.33 & $0.32 \mathrm{a}$ & 0.80 & 0.85 & $0.83 \mathrm{a}$ \\
\hline $\mathrm{a}_{6}$ & $500 \mathrm{~kg} \mathrm{~N} / \mathrm{ha}$ & 2.10 & 2.40 & $2.25 \mathrm{~d}$ & 0.28 & 0.31 & $0.30 \mathrm{a}$ & 0.76 & 0.88 & $0.82 \mathrm{a}$ \\
\hline $\mathrm{a}_{7}$ & $600 \mathrm{~kg} \mathrm{~N} / \mathrm{ha}$ & 2.27 & 2.57 & $2.42 \mathrm{~d}$ & 0.29 & 0.31 & $0.30 \mathrm{a}$ & 0.76 & 0.93 & $0.85 \mathrm{a}$ \\
\hline \multicolumn{2}{|c|}{ Av. (a) } & $1.83 \mathrm{a}^{*}$ & $2.02 \mathrm{~b}$ & - & $0.29 \mathrm{a}^{*}$ & $0.30 \mathrm{a}$ & - & $0.75 \mathrm{a}^{*}$ & $0.82 \mathrm{~b}$ & - \\
\hline
\end{tabular}

$\mathrm{b}_{1}$ - corresponds to $\mathrm{N}_{0} \mathrm{P}_{0} \mathrm{~K}_{0}$ (without mineral fertilization), $\mathrm{b}_{2}$ - corresponds to $\mathrm{N}_{100} \mathrm{P}_{100} \mathrm{~K}_{100}$ (mineral fertilization) Av. - average

*Mean values accompanied by same letter (a or b) does not present significant differences (Tukey multiple comparison

test - significance level 0.05)

In the case of applied sludge with and without mineral fertilization, the corresponding nitrogen doses correlate statistically very strong with the nitrogen content in grains.

The phosphorus and potassium content in grains analysis correlated with the nitrogen doses resulting from variants with sludge and mineral fertilization reveals statistically strong correlation coefficients (Figures 1, 2, 3).

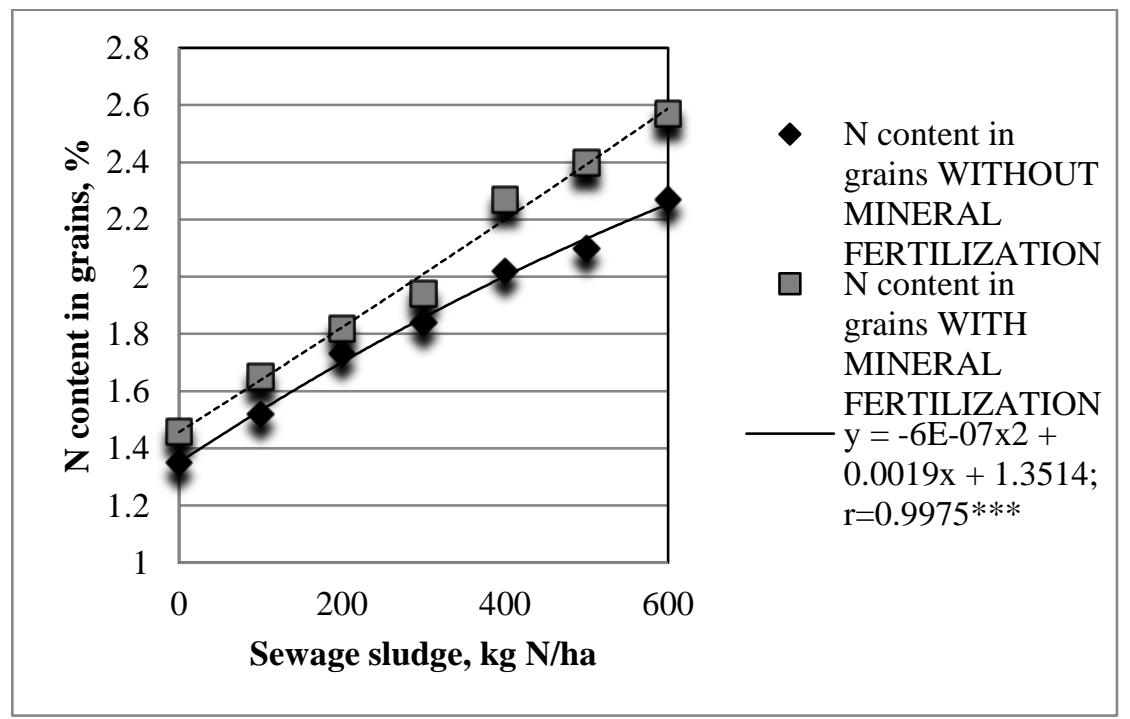

Figure 1. Correlation between nitrogen content in grains and applied nitrogen dose $(* * *$ very strong correlation, $\mathrm{p}<0.001)$ 


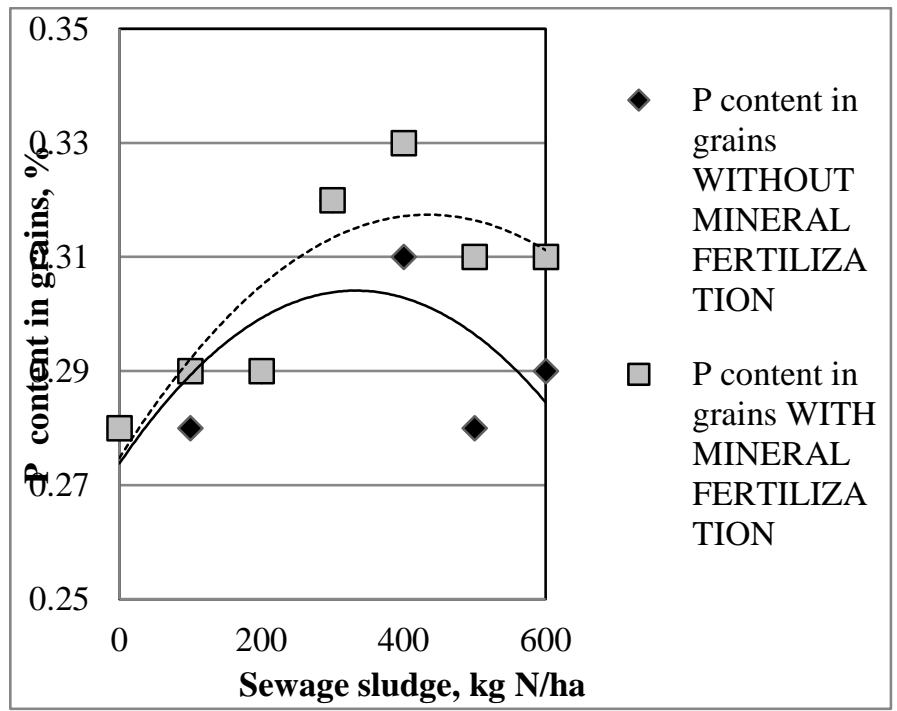

Figure 2. Correlation between phosphorus content in grains and applied nitrogen doses $(* *$ strong correlation, $0.001<\mathrm{p}<0.01$ )

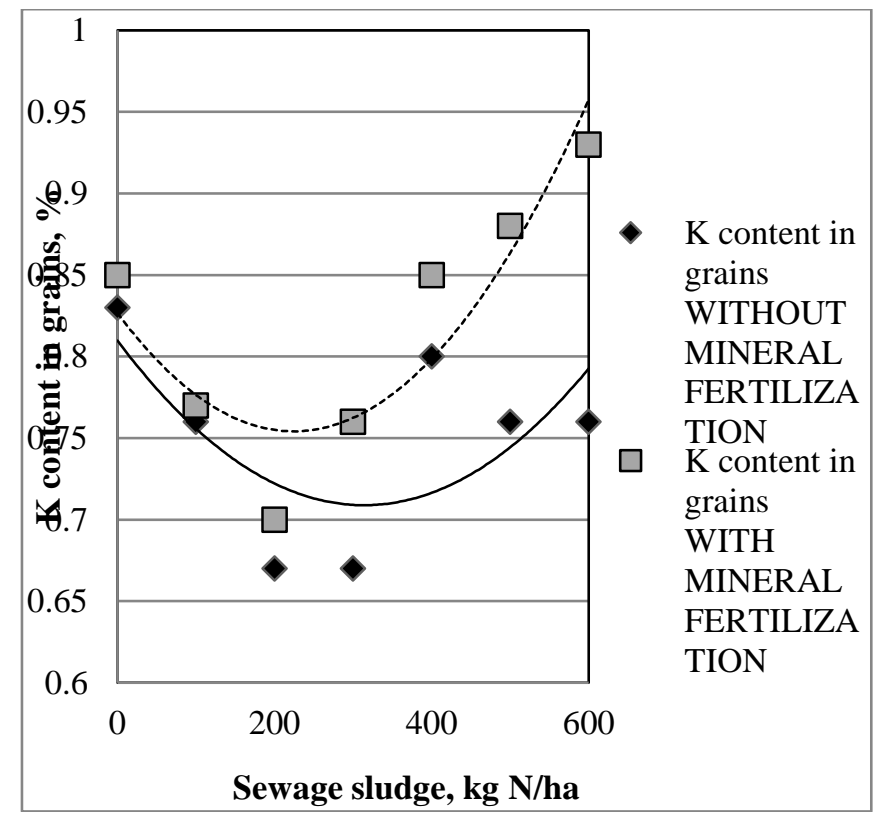

Figure 3. Correlation between potassium content in grains and applied nitrogen doses $(* *$ strong correlation, $0.001<\mathrm{p}<0.01)$

\subsection{Influence of sewage sludge application on $\mathrm{Ca}$ and $\mathrm{Mg}$ contents in grains}

Calcium contents in oat grains present a significant increase after fertilization with sewage sludge, the values being statistically assured after application of a dose equivalent with $400 \mathrm{~kg} \mathrm{~N} / \mathrm{ha}$. At a dose equivalent with $600 \mathrm{~kg} \mathrm{~N} / \mathrm{ha}$, the calcium levels (0.24\%) increased 3 times in comparison with untreated variant $(0.08 \%)$ (table 6$)$. Mineral fertilization, accompanied or not by organic fertilization did not led to significant changes of calcium in oat grains, the obtained values being similar with those obtained after organic fertilization.

Similar calcium levels were reported by Jakobsone et al. for oat grains [31, 32]. Del Coco et al. found the same calcium levels in wheat grains [30]. 
Fertilization with sewage sludge, associated or not with mineral fertilizers, did not produced significant changes of magnesium levels in oat grains, found concentrations being considered as normal values and in agreement with those reported for cereal grains [29].

Table 6. Influence of sewage sludge application (without/with mineral fertilization) on $\mathrm{Ca}$ and $\mathrm{Mg}$ contents in grains

\begin{tabular}{|c|c|c|c|c|c|c|c|}
\hline \multicolumn{2}{|c|}{ Sewage sludge } & \multicolumn{3}{|c|}{ Сa,\% } & \multicolumn{3}{|c|}{$\mathrm{Mg}, \%$} \\
\hline & & $\mathrm{b}_{1}$ & $\mathrm{~b}_{2}$ & Av. (b) & $\mathrm{b}_{1}$ & $\mathrm{~b}_{2}$ & Av. (b) \\
\hline $\mathrm{a}_{1}$ & $0 \mathrm{~kg} \mathrm{~N} / \mathrm{ha}$ & 0.09 & 0.07 & $0.08 \mathrm{a}^{*}$ & 0.24 & 0.22 & $0.23 \mathrm{a}^{*}$ \\
\hline $\mathrm{a}_{2}$ & $100 \mathrm{~kg} \mathrm{~N} / \mathrm{ha}$ & 0.10 & 0.10 & $0.10 \mathrm{a}$ & 0.23 & 0.24 & $0.24 \mathrm{a}$ \\
\hline$a_{3}$ & $200 \mathrm{~kg} \mathrm{~N} / \mathrm{ha}$ & 0.13 & 0.11 & $0.12 \mathrm{ab}$ & 0.25 & 0.23 & $0.24 \mathrm{a}$ \\
\hline$a_{4}$ & $300 \mathrm{~kg} \mathrm{~N} / \mathrm{ha}$ & 0.12 & 0.12 & $0.12 \mathrm{ab}$ & 0.24 & 0.24 & $0.24 \mathrm{a}$ \\
\hline a5 & $400 \mathrm{~kg} \mathrm{~N} / \mathrm{ha}$ & 0.15 & 0.19 & $0.17 b c$ & 0.24 & 0.27 & $0.26 \mathrm{a}$ \\
\hline$a_{6}$ & $500 \mathrm{~kg} \mathrm{~N} / \mathrm{ha}$ & 0.18 & 0.20 & $0.19 \mathrm{~cd}$ & 0.26 & 0.28 & $0.27 \mathrm{a}$ \\
\hline$a_{7}$ & $600 \mathrm{~kg} \mathrm{~N} / \mathrm{ha}$ & 0.24 & 0.23 & $0.24 \mathrm{~d}$ & 0.25 & 0.27 & $0.26 \mathrm{a}$ \\
\hline & Av. (a) & $0.14 a^{*}$ & $0.15 a$ & - & $0.24 a^{*}$ & $0.25 a$ & - \\
\hline
\end{tabular}

$b_{1}$ - corresponds to $\mathrm{N}_{0} \mathrm{P}_{0} \mathrm{~K}_{0}$ (without mineral fertilization), $\mathrm{b}_{2}$ - corresponds to $\mathrm{N}_{100} \mathrm{P}_{100} \mathrm{~K}_{100}$ (mineral fertilization) Av. - average

*Mean values accompanied by same letter (a or b) does not present significant differences (Tukey multiple comparison test - significance level 0.05)

The content of calcium in oat grains correlates statistically very strong with nitrogen doses corresponding to the application of sludge in experimental variants with/without mineral fertilization (Figure 4). The magnesium content in grains correlates statistically strong with nitrogen doses from variants with mineral fertilization and for those without mineral fertilization the coefficient reveals statistically a not- significant correlation (Figure 5).

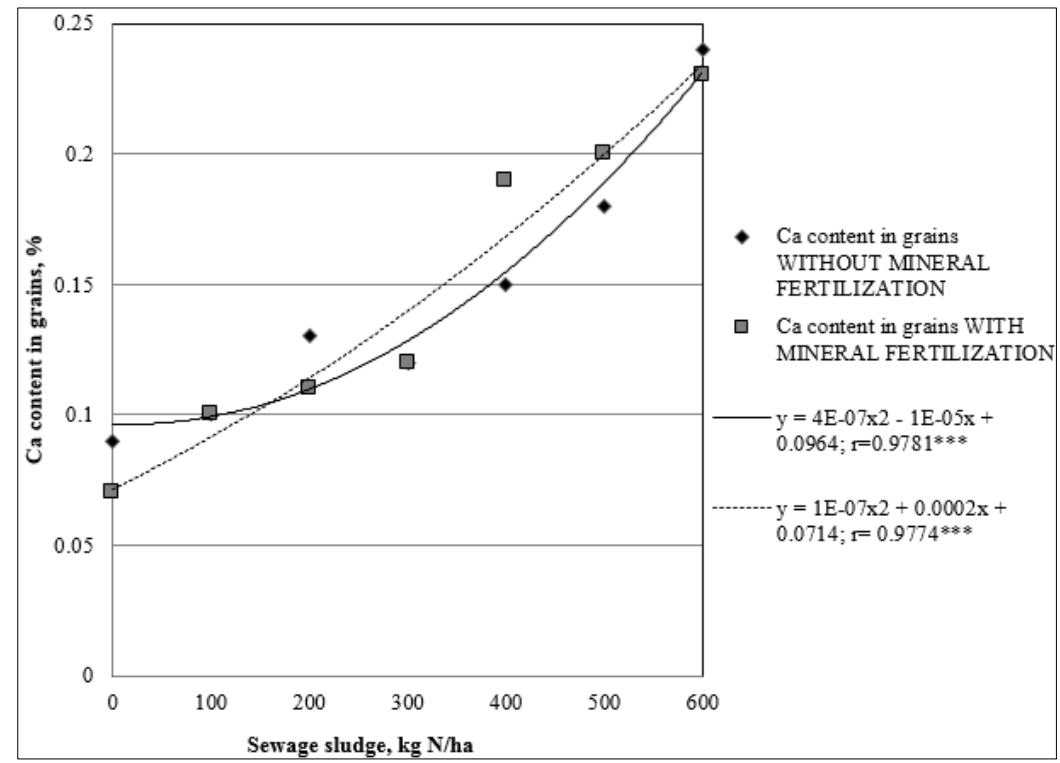

Figure 4. Correlation between calcium content in grains and applied nitrogen doses $(* * *$ very strong correlation, $\mathrm{p}<0.001)$ 


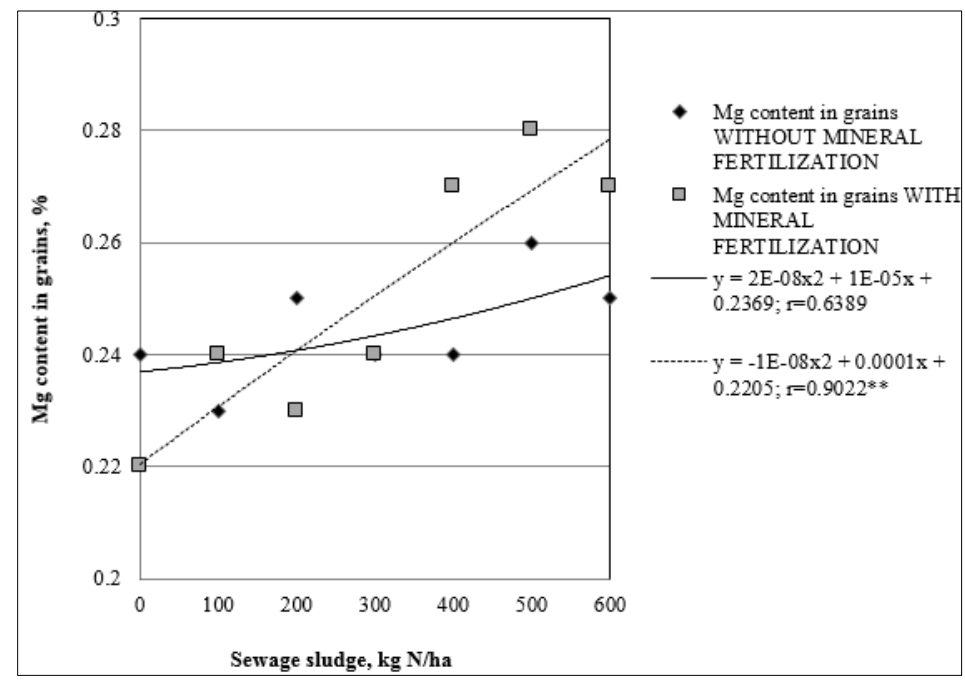

Figure 5. Correlation between magnesium content in grains and applied nitrogen doses $(* *$ strong correlation, $0.001<\mathrm{p}<0.01)$

\section{Conclusions}

Based upon the findings of this study, the main conclusions are presented below.

Starting with equivalent dose of $100 \mathrm{~kg} \mathrm{~N} / \mathrm{ha}$, sewage sludge application produce significant increase of plant height. The highest height was recorded in the case of doses equivalent with 300 and $400 \mathrm{~kg} \mathrm{~N} / \mathrm{ha}$.

Grains yields increase significant with sewage sludge application, the highest value, as average being obtained for sewage dose equivalent with $500 \mathrm{~kg} \mathrm{~N} / \mathrm{ha}$ and $600 \mathrm{~kg} \mathrm{~N} / \mathrm{ha}$. Mineral fertilization led to significant oat grains yield in comparison with unfertilized variant. Also, straw yield increased with sewage sludge doses.

Sewage sludge application associated with mineral fertilizers does not provide significant statistical increases of grains yield and straw yield but these parameters are slightly higher in comparison with the variants fertilized organic only.

Nitrogen contents in oat grains increases with applied sewage sludge dose, being significant from an equivalent dose of $200 \mathrm{~kg} \mathrm{~N} / \mathrm{ha}$. No significant changes were recorded for phosphorus levels in oat grains in the case of sewage sludge application, associated or not with mineral fertilizers.

At low sewage sludge doses equivalent with $200-300 \mathrm{~kg} \mathrm{~N} / \mathrm{ha}$, potassium concentration in oat grains after sewage sludge application present a significant decrease in comparison with untreated variant.

Calcium contents in oat grains present a significant increase after fertilization with sewage sludge, the values being statistically assured after application of a dose equivalent with $400 \mathrm{~kg} \mathrm{~N} / \mathrm{ha}$.

Organic fertilization accompanied or not by mineral one, did not led to significant changes of calcium and magnesium in oat grains.

\section{References}

1. AGHILINATEGH, N., HEMMAT, A., REZAINEJAD, Y., SADEGHI, M., XXXIIICIOSTA-CIGR V Conference, Reggio Calabria, Italy, Technology and management to ensure sustainable agriculture, agrosystems, forestry and safety, 2, 2009, p. 1059.

2. AILINCAI, C., JITAREANU, G., BUCUR, D., AILINCAI, D., Cercetari Agronomice in Moldova, XLV, 1(149), 2012, p. 5.

3. URBANIAK, M., WYRWICKA, A., TOLOCZKO, W., SERWECINSKA, ZIELINSKI M., Sci.Total Environ., 586, 2017, p. 66.

4. TANASE, V., VRINCEANU, N., PREDA, M.,MOTELICA, D.M., AgroLife Scientific Journal, 6(2), 2017, p. 195. 
5. MIHALACHE, M., ILIE, L., MADJAR, R., Rev. Roum. Chim., 59(2), 2014, p. 81.

6. KAMAL, A.T.M.M., ISLAM, M.M., HOSSAIN,M.S., ULLAH, S.M., Bangladesh J. Sci. Res., 26(1\&2), 2013, p. 57.

7. ILIE, L., MIHALACHE, M., MADJAR, R.M., CALIN, C., SCAETEANU VASILE, G., Rev.Chim., 69, no. 3, 2018, p. 561.

8. ILIE, L., MIHALACHE, M., SCAETEANU VASILE, G., MADJAR, R.M., POPOVICI, D.R., Rev.Chim., 69, no. 5, 2018, p. 1166.

9. MORERA, M.T., ECHEVERRIA, J., GARRIDO, J., Can. J. Soil Sci., 82, 2002, p. 433.

10. MIHALACHE, M., ILIE, L., MADJAR, R.M., CALIN, C., SCAETEANU VASILE, G., Rev.Chim., 66, no. 7, 2015, p. 951.

11. COCARTA, D.M., SUBTIRELU, V.R., BADEA, A., Environ. Eng. Manag. J., 16, no. 5, 2017, p. 1093.

12. THEODORATES, P., MOIROU, A., XENIDIS, A., PASPALIARIS, I., Hazard. Mater., B77, 2000, p. 177.

13. TSAKOU, A., ROULIA, M., CHRISTODOULAKIS, N.S., Bull. Environ. Contam.Toxicol., 68, 2002 , p. 56.

14. ENASCUTA, C.E., STEPAN, E., OPRESCU, E.E., RADU, A., ALEXANDRESCU, E., STOICA, R., EPURE, D.G., NICULESCU, M.D., Rev. Chim., 69, no. 7, 2018, p. 1612.

15. NEAMT, I., IONEL, I., FLORESCU, C., Rev.Chim., 63, no. 7, 2012, p. 739.

16. PREDA, M., DUMITRU, M., VRINCEANU, N., TANASE, V., Scientific Papers, UASVM Bucharest, Series A, LIII, 2010, p. 141.

17. ALHAFEZ, L., MUNTEAN, N., MUNTEAN, E., RISTOIU, D., Bulletin UASMV, Agriculture, 70, no. 2, 2013, p. 387.

18. OZCAN, S., TOR, A., AYDIN, M. E., Clean Soil Air Water, 41, 2013, p. 411.

19. DUMONTET, S., DINEL, H., BALODA, S.B., Biol. Agric. \& Hort., 16, no. 4, 1999, p. 409.

20. AZAM, F., ASHRAF, A., LODHI, A., GULNAZ, A., Irradiated sewage sludge for application to cropland, IAEA-TECDOC-1317; IAEA, Vienna, 2002, p. 145.

21. COSTICA, A., GERARD, J., DANIEL,B., DESPINA, A., J. Food, Agric. Environ. 5, 2007, p. 310.

22. CHATHA, T.H.,HAYA, R.,LATIF, I., Asian J..Plant Sci., 1, 2002, p. 79.

23. SINGH, R.P., AGRAWAL, M., Chemosphere, 67, 2007, p. 2229.

24. FAO.1998. World Reference Base for Soil Resources, by ISSS-ISRIC-FAO. World Soil Resources Report, No. 84, Rome.

25. Council Directive 86/278/EEC of 12 June 1986 on the protection of the environment, and in particular of the soil, when sewage sludge is used in agriculture.

26. Order of the Minister of Agriculture, Forests, Waters and Environment no.344/2004 for the approval of Technical Guidelines on the protection of the environment.

27. DUMitru, M., MOTELICĂ, D.M., ALEXANDRESCU, A., PlAXIENCO, D., GAMENT,, E., DUMITRU, E., VRÎNCEANU, N., Irradiated sewage sludge for application to cropland, IAEATECDOC-1317; IAEA, Vienna, 2002, p. 171.

28. KOIVISTOINEN, P., NISSINEN, H., VARO, P., AHLSTROM, A., Acta Agric. Scand., 24(4), 1974, p. 327.

29. KAN, A., Rec.Nat.Prod.J., 9(1), 2015, p. 124.

30. DEL COCO, L., LADDOMADA, B., MIGONI, D., MITA, G., SIMEONE, R., FANIZZI, F.P., Sustainability, 11, 2019, p. 736.

31. JAKOBSONE, I., ZUTE, S., BLEIDERE, M., KANTANE, I., ECE, L., BARTKEVICS, V., Zemdirbyste-Agriculture, 106, no.1, 2019, p. 21.

32. JAKOBSONE, I., KANTANE, I., ZUTE, S., JANSONE, I., BARTKEVICS, V., Proceedings of the Latvian Academy of Sciences, section B, 69, no.4, 2015, p. 152. 